\title{
放送コンテンツの著作権保護における電子透かしの利用方法
}

\section{Watermarking Applications for Broadcast Content Copyright Protection}

\author{
正会員山田隆亮 ${ }^{\dagger}$, 吉浦 裕 ${ }^{\dagger \dagger}$, 正会員 越前 功 ${ }^{\dagger}$, 正会員小川一人什, \\ 正会員 室田逸郎 ${ }^{\dagger \dagger}$, 正会員 大竹 剛 ${ }^{\dagger \dagger}$, 正会員 合志清一
}

Takaaki Yamada ${ }^{\dagger}$, Hiroshi Yoshiura ${ }^{\dagger \dagger}$, Isao Echizen ${ }^{\dagger}$, Kazuto Ogawa ${ }^{\dagger \dagger}$, Itsuro Murota ${ }^{\dagger \dagger \dagger}$, Go Ohtake ${ }^{\dagger \dagger \dagger}$ and Seiichi Gohshi ${ }^{\dagger \dagger}$

\begin{abstract}
Copyright protection of broadcast content has become an issue of great concern because digital broadcasting is increasingly used to deliver high quality visual and audio content. We analyze the existing copyright protection technologies and clarify why they cannot prevent illegal copies from being created through the analogue output of broadcast receivers. Illegally copied content can thus be re-digitized and distributed through the Internet and portable media. Digital watermarking that survives analogue processes effectively complements existing technologies. Four methods of using watermarking to detect illegal copies, copiers, and distributors are described and compared with respect to their implementation cost, detection ability, and ease of deployment. The technical requirements of the watermarking used in these methods are also clarified with respect to survivability against analogue processes, maintenance of image quality, and quantity of embedded information.
\end{abstract}

キーワード : 放送, 放送コンテンツ, 不正コピー，電子透かし，著作権保護

\section{1. まえがき}

放送のディジタル化に伴って，高精細かつ高音質のコ ンテンツを放送できるようになってきた。 また，ディジ タル録画, 双方向放送, デー夕放送などの多様な新サ一 ビスの提供が可能になってきた ${ }^{1) \sim 4)}$.

一方, DVD(Digital Versatile Disc) などの大容量記録 媒体を用いた映像や音声の流通が進むとともに，インタ ネットの広帯域化によって，ネットワークを通じた映像 や音声の配信サービスも可能になってきた ${ }^{5) ~ 7) . こ の よ ~}$ うに，ディジタル化技術，それを用いた放送，記録媒体， ネットワーク技術の発展により, 多種多様なコンテンツ サービスが可能となっている.

ところが，これらの技術の負の側面として，高画質，

2002 年 7 月 9 日受付, 2003 年 5 月 7 日最終受付, 2003 年 6 月 6 日採録 †（株）日立製作所 システム開発研究所

（广 244-0817 横浜市戸塚区吉田町 292 番地, TEL 045-860-3073） 碑㫣通信大学 電気通信学部

（テ 182-8585 東京都調布市調布ヶ丘 1-5-1, TEL 0424-43-5517) †† NHK 放送技術研究所

（广 157-8510 世田谷区砧 1-10-11, TEL 03-5494-3178)

† Systems Development Laboratory, Hitachi,Ltd. (292 Yoshida-Cho, Totsuka-ku, Yokohama, 244-0817 Japan)

††Department of Electro-Communications, The University of Electro-Communications

(1-5-1, Choufugaoka, Choufu, Tokyo, 182-8585 Japan)

†† NHK Science and Technical Research Laboratories (1-10-11, Kinuta, Setagaya-ku, 157-8510 Japan)
高音質の放送コンテンツを不正にコピーし，媒体やイン ターネットを通じて配布することが容易になっている. そのため, 放送局や番組制作会社および素材提供会社な どの著作権が侵害されることが䯚念されている ${ }^{8) 9}$.

この著作権侵害を防止する新しい要素技術として，コ ンテンツに著作権情報を挿入する電子透かし技術 ${ }^{10) ~ 13) ~}$ が期待されている.

しかし，著作権侵害を防止する技術としては，従来か ら, 暗号, 認証, 耐タンパー処理など様々なものが実用 化されており, 問題の多くは従来技術によって解決でき ると考えられる ${ }^{14) \sim 16)}$. また, 電子透かしの利用につい ても, ネットワーク配信の分野では様々な検討が行われ ている ${ }^{17) 18) .}$

したがって, 電子透かし技術の健全な発展と放送コン テンツのより強固な著作権保護のために, 従来技術の存 在を前提とし，ネットワーク配信と放送との相違を明ら かにした上で，放送における電子透かしの有用性および 有効な利用方法を明らかにすることが重要である.

そこで本論文では, 現在利用されている放送コンテン ツ用著作権保護技術を分析し, ネットワークと放送の相 違を明確化した上で, 放送における電子透かしの利用方 法を提案する. 以下, 2 章では従来技術の分析, 3 章で は電子透かしの役割の明確化, 4 章ではネットワークと 放送の相違を前提とした電子透かしの利用方法の提案を 


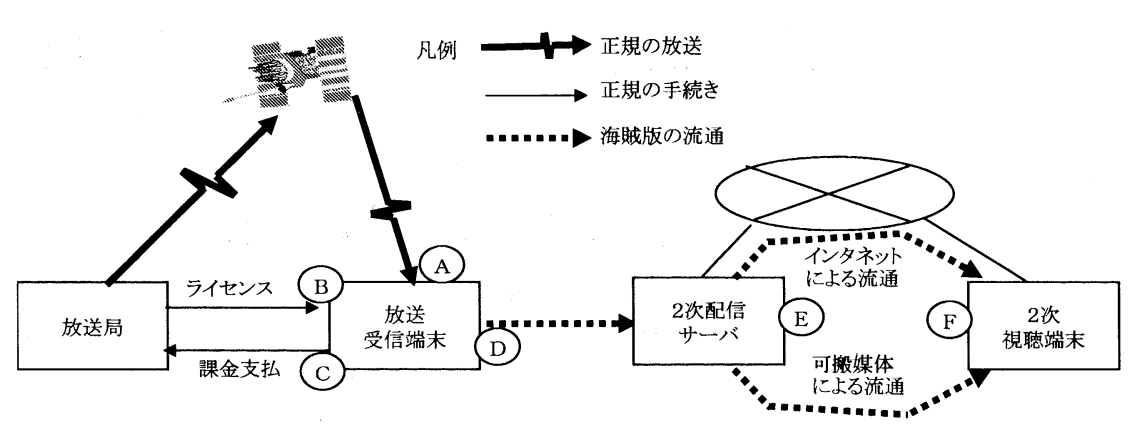

図 1 放送コンテンツの流通モデル

Circulation model of broadcasting contents.

行う.

\section{2. 従来の放送コンテンツ用著作権保護技術の分析}

\section{1 用語の定義}

放送コンテンツの著作権侵害に関わる用語を，次のよ うに定義する.

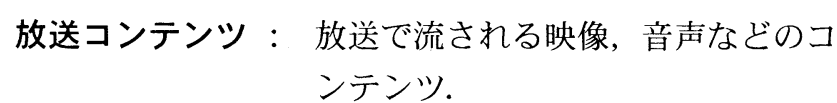

放送視聴者： 放送コンテンツを視聴する主体.

放送受信機： 放送視聴者が放送コンテンツを受信 する端末.

2 次コンテンツ： 放送コンテンツをコピーおよび編集 し, ネットワークや可搬媒体を通じ て流通させたコンテンツ.

2 次配信サーバ： 2 次コンテンツを配信するサーバ.

2 次配信者 ：2 次コンテンツを配信する主体.

2 次視聴端末：2 次コンテンツを視聴する端末. 視 聴に必要な機能（例えばネットワー ク経由の受信）を含む.

\section{2 次視聴者 ： 2 次コンテンツを視聴する主体。}

\section{2 前提となる流通モデル}

本論文の分析の前提となる放送コンテンッの流通モ デルを図 1 に示す. 図中, 実線は正規のコンテンツ流通 を示す. 破線は不正なコンテンツ流通, $\mathrm{A} \sim \mathrm{F}$ は不正行 為の劦威がある場所を示しており, その詳細は次節で述 ベる.

放送局から放送視聴者への正規の流通は, 次の 4 フエー ズからなる.

・放送局は, 放送コンテンツを放送し; 放送視聴者は これを受信する。

・放送局は，放送視聴者に放送コンテンツの利用ライ センスを許諾, 付与する.

・放送局は，放送視聴者に利用料金を請求，回収する.

・放送視聴者は，放送コンテンツを視聴，蓄積する.
さらに，放送受信機において，不正コピーコンテンツ （海賊版）が作成された場合を想定すると，2次配信者 からネットワークや可搬媒体を介して海賊版が配信され, 2 次視聴端末で視聴される. 2 次利用が不正行為の基本 形であり，2次利用を阻止できなかった場合に，2次視 聴者から 2 次配信者に流れる繰り返しループ（3 次の不 正流通）が生じる.

本論文では, 放送コンテンツに対する電子透かしの役 割を明らかにし, 利用方法を限定することにより, 現害 的な著作権保護方法を提案しようとしている. そこで, 議論の発散を避けるために, 下記の前提の下に, 最も基 本的な流通のみを取り上げることとする.

・放送局の不正行為はないとする.

・放送電波をエッジサーバ（インターネット上でコン テンツ配信を直接ユーザに行う末端のサーバ）で受信し， 放送コンテンツをネットワーク経由で配信するサービス を議論から除く.

\section{3 著作権侵害に関する脅威}

放送の正規の手続き（四つのフェーズ）には，それぞ れ次の著作権侵害に関する脅威がある.

（A） ライセンスを取得していない第 3 者が不正に受 信し，電波を解析して，コンテンツを利用する.

（B）放送視聴者が契約で定めた範囲外（指定期限後 あるいは指定端末以外での視聴など）に利用する.

（C）放送視聴者が料金をごまかす.

（D） 視聴時に暗号解除されたコンテンツ，あるいは， 蓄積されたコンテンツを放送視聴者が不正コピー し, 再配布する.

もしも（D）の劦威により, 不正コピーコンテンツが 作成された場合, 以下の過程を経て実害に至る.

（E） 2 次配信者が不正コピーコンテンツを配信する.

（F） 2 次視聴者が不正コピーコンテンツを視聴する.

（A）〜（F）の不正行為による劦威を表 1 に示す.

\section{4 従来技術の分析}

(1) 概 要

前述した脅威への従来の対策技術を表 2 に示す.

まず, 劦威（A）（B）（C）に対しては, CAS（限定 受信システム : Conditional Access System）によって対 


\begin{tabular}{|c|c|c|}
\hline & フェーズ & 脅威 \\
\hline 正 & 放送コンテンツを送信，受 & （A） ライセンスを取得していない \\
\hline 規 & & ユーザが勝手に受信し，電波を解析 \\
\hline の & & して, コンテンツを利用 \\
\hline 流 & 利用ライセンスの許諾（放 & （B）ユーザが契約で定めた範囲外 \\
\hline れ & 送局がユーザに付与） & $\begin{array}{l}\text { の利用（指定期限後あるいは指定端 } \\
\text { 末以外での視聴など） }\end{array}$ \\
\hline & 料金請求, 回収 & （C）ユーザが料金をごまかし \\
\hline & $\begin{array}{l}\text { 放送コンテンツの視聴，蓄 } \\
\text { 積 }\end{array}$ & 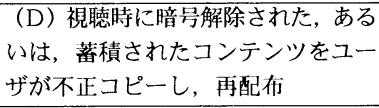 \\
\hline 海 & $\begin{array}{l}\text { 不正コピーされたコンテン } \\
\text { ツをネット上で配信 }\end{array}$ & （E）不正コピーの配信 \\
\hline 版 & $\begin{array}{l}\text { 不正コピーされたコンテン } \\
\text { ツを視聴 }\end{array}$ & (F) 不正コピーの視聴 \\
\hline
\end{tabular}

表 2 不正行為対策技術の効果

Countermeasure effect.

\begin{tabular}{|c|c|c|}
\hline 不正行為が行われる可能性 & 不正行為対策 & 効果 \\
\hline $\begin{array}{l}\text { （A）ライセンスを取得していないユー } \\
\text { ザが勝手に受信し，電波を解析して，コ } \\
\text { ンテンツを利用 }\end{array}$ & \multirow[t]{4}{*}{$\begin{array}{l}\text { 暗号, 受信限定 } \\
\text { (CAS) }\end{array}$} & \multirow[t]{4}{*}{ O } \\
\hline (B) ユーザが契約で定めた笧囲外の利 & & \\
\hline $\begin{array}{l}\text { 用（指定期限後あるいは指定端末以外で } \\
\text { の視聴など） }\end{array}$ & & \\
\hline (C) ユーザが料金をごまかし & & \\
\hline $\begin{array}{l}\text { （D）視聴時に暗号解除されたコンテン } \\
\text { ツ, あるいは, 蓄積されたコンテンツを } \\
\text { ユーザが不正コピーし, 再配布 }\end{array}$ & $\begin{array}{l}\text { 暗号, 認証, 耐夕 } \\
\text { ンパー処理 }\end{array}$ & $\triangle$ \\
\hline
\end{tabular}

策している ${ }^{14) 15) .}$

CAS は，放送を視聴できる受信者を限定するシステム である. 例えば, BS デジタル放送の CAS(B-CAS) では, 放送コンテンツに暗号化処理（スクランブル）を行って 放送する. IC カードに入れて, 放送視聴者に配布したマ スタ一鍵により個別化を行い，ワーク鍵，スクランブル 鍵の管理を通じて，正当な視聴者が契約通りに視聴する 場合の夕暗号の解除を可能とする.

CAS では，放送コンテンツが暗号によって保護され， さらに暗号の鍵の内，ワーク鍵およびスクランブル鍵は マスター鍵によって保護され，さらにマスター鍵は IC カードによって保護される. IC カードは, 耐タンパー処 理 ${ }^{19)}$ と呼ばれる技術により, 内部への侵入を防止可能 となっている.このように, CAS は確立された技術であ り, その著作権保護機能は強固である.

そこで, 残る劦威である（D）（視聴時に暗号解除さ れたコンテンツあるいは蓄積されたコンテンツの不正コ ピー）が問題となる．次節では，劦威（D）をさらに詳 細に分析し, 従来技術の問題点を明らかにする.

(2) 不正コピーへの対策

放送受信機において，不正コピーの劦威となる経路は 4 個所ある.

・装置のこじ開け $(\mathrm{D}-1)$

・ディジタル信号出力経由 (D-2)

・内蔵ディスク経由 (D-3)

・アナログ信号出力経由 (D-4)
これらの艿威と，その対策技術の主だったものを図 2 に示す. また，これらの対策技術の効果を表 3 に示す. 以下では，対策技術の効果について詳細を述べる.

$(D-1)$ 装置のこじ開け

装置をこじ開けて，LSI 内部端子にプローブ接続し， 動作中の波形をリアルタイムで記録したり, 内部バスの データを読み出す不正行為などが想定される。これらの 艿威に対して，放送受信機で而タンパー処理を設けてい る. 耐夕ンパー処置は確立された技術であり, 強固な保 護が可能である ${ }^{19)}$.

\section{（D-2）ディジタル信号出力経由}

放送受信機のディジタル信号出力に対して, モニタ を接続する替わりに録画機を接続して, 放送コンテン ツを不正にコピーするなどの方法が劦威として存在す る。これらの脅威に対して, DTCP（Digital Transmission Content Protection) ${ }^{20)}$, HDCP (High-bandwidth Digital Content Protection） ${ }^{2122)}$ などの規格によって対 策している.

DTCP は，IEEE1394 を介した不正コピーを防止する ための規格である. DTCP では, データごとに, コピー 制御情報の種別（「コピーフリー」,「コピー不可」など） を識別，管理する．また，データの出力先機器が規格に 則った機器であることを確認する．さらに，機器の種別 （録画機能の有無など）を認識することで, デー夕送信 の可否を判断する. さらに, 送信時にはデー夕を暗号化 することで，通信路での盗用を防止する.

HDCP は，コンテンツのディジタル信号をディジタル モニ夕に出力する上での認証や暗号化などを定義した仕 様である. DTCP および HDCP は確立された技術であ り, 強固な保護が可能である.

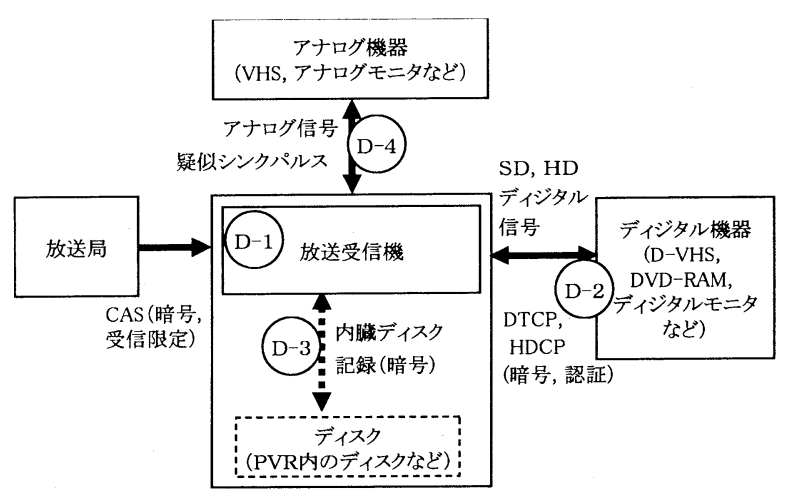

図 2 不正コピー対策技術

Technologies of illegal copy countermeasure.

表 3 不正コピー対策の効果

Effect of illegal copy countermeasures.

\begin{tabular}{l|l|l}
\hline \hline \multicolumn{1}{c|}{ 不正コピーが行われる可能性 } & \multicolumn{1}{|c}{ 不正コピー対策 } & \multicolumn{1}{c}{ 効果 } \\
\hline (D-1) 装置のこじ開け & 耐タンパー処理 & $\bigcirc$ \\
\hline (D-2) ディジタル信号出力経由 & 認証, 暗号 & $\bigcirc$ \\
\hline (D-3) 内蔵ディスク経由 & 暗号 & $\bigcirc$ \\
\hline (D-4) アナログ信号出力経由 & 疑似シンクパルス & $\triangle$ \\
\hline
\end{tabular}

(103) 1157 


\section{（D-3）内蔵ディスク経由}

放送受信機の中には，ディスクを内蔵した PVR （Personal Video Recorder）の機能を持つものがある. この内蔵ディスクを解析して放送コンテンツを不正コ ピーされる劦威がある ${ }^{23)}$.

この妿威への対策として, PVR では, ディスク格納時 に，放送コンテンツを暗号化しておくことが規定されて いる. すなわち，仮にデータを取り出せても，そのデー タがコンテンツとして視聴できないようにしている ${ }^{24)}$.

（D－4）アナログ信号出力経由

アナログ信号の出力（アナログ出力）を録画し，再 ディジタル化して配信される劦威がある.

この脅威に対しては, 疑似シンクパルス ${ }^{25226)}$ が一般的 な対策である．この技術は，映像信号の一部に特殊な信 号を埋込んでおくことにより，閲覧制御を行うものであ る. しかし，この方式による不正防止は一定の効果はあ るものの，暗号や認証のような理論的に保障された技術 と比べると，万全ではない．また，HD(High Definition) アナログ出力に関しては，擬似シンクパルスは装備され ていない。

\section{5 従来技術のまとめ}

コンテンツの正規の流れにおいて想定された（A）電 波の解析, (B) 契約外の視聴, (C) 料金のごまかし, の 不正行為は, C A S により防止できる. (D) の不正行為 の内, 装置のこじ開け, ディジタル信号出力経由, 内臓 ディスク経由の不正コピーは, 耐タンパー処理, 暗号, 認証技術により防止できる. すなわち, ディジタル状態 のコンテンツに対する直接の不正行為は防止することが できる.

しかし，アナログ出力を介した不正コピー（D-4） に対しては，対策が万全ではない，アナログ出力で一旦 不正コピーされると, 再ディジタル化を通じて, 可搬媒 体やインタネットを通じた不正配信が可能となる．オリ ジナルコンテンツの高品質化に伴い, アナログ出力経由 で再ディジタル化したものも，充分視聴に耐える品質と なる.

以上述べたように, 従来技術はアナログ出力経由の不 正コピーに対して, 万全ではない. また, アナログ出力 経由の不正コピーは, 実質的にディジタルの直接コピー に近い大きな劦威となりうる．そこで，以下の章では， アナログ出力経由の不正コピー, および不正コピーされ たコンテンツの不正流通を防止する技術として, 電子透 かしの有効性を考察する.

\section{3. 電子透かし}

\section{1 電子透かしの機能}

電子透かしは，映像や音楽などのコンテンツに情報を 挿入し，また，挿入した情報をコンテンツから検出する

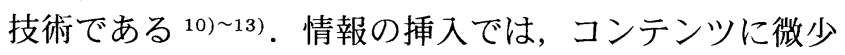

な変更を加えることで行う．そして，変更した場所と変 更内容によって情報を表わす．したがって，オリジナル コンテンツと情報を挿入したコンテンツは, 人間の視覚 や聴覚には同じに感じられるが, わずかに異なっている. 情報の検出では, コンテンツに加えられた変更を読取る ことで, 挿入した情報を検出する.

電子透かしは以下の特徵を有する. 情報をコンテンツ のヘッダーなどの外部デー夕に記述するのではなく, 直 接埋込む. そのため, コンテンツ自体の特徴が変わらな い限り, 埋込んだ情報は生き残り, 後で検出することが できる. したがって，一旦アナログ信号に変換した後で も, 再ディジタル化することで挿入した情報を検出する ことができる ${ }^{10) 35) .}$

また，不正コピーの作成者が意図的に行ったり，不正 流通の過程で行われる様々な画像処理, 音響処理に耐え る. 例えば，画像用電子透かしの場合，JPEG, MPEG などの非可逆圧縮，平滑化などのフィルタリング，一部 切り取りなどの様々な画像処理を加えた後でも, 挿入し た情報を検出できるものがある ${ }^{13)}$. 一方, 音楽・音声用 電子透かしの場合も, 部分切出し, 周波数フィルタなど の様々な音響処理に耐えるものがある ${ }^{12)}$.

\section{2 電子透かしの役割}

2 章では, 不正コピーコンテンツの流通（すなわち放 送受信者が放送受信機からコンテンツを不正コピーし， これを配布すること）に関する妿威を明らかにした。本 節では, この脅威への対策に用いる場合の, 電子透かし の役割を明らかにする。

（1） 海賊版の流通モデル

分析に先だって，まず不正コピーコンテンツの流通モ デルを明らかにする（図 3 ）。

不正コピーコンテンツ流通の関与者は，不正コピーを 作成する作成者，それを配信する 2 次配信者，それを視 聴する 2 次視聴者である. 不正コピ一作成者は放送視聴 者と同じ者である.これらの関与者のなす不正行為は, (D) 不正コピーの作成行為, (E) 不正コピーの配信行 為, $(\mathrm{F})$ 不正コピーの視聴行為である.

（2）電子透かしを用いた不正対策

不正コピー対策に限らず，一般に，セキュリティ技術 には直接的対策と間接的対策がある（図 4) ${ }^{28)}$. 直接的 対策は, 不正行為を直接差し止めるものであり, 海賊版 流通防止の場合は，不正コピーの作成行為を差し止める

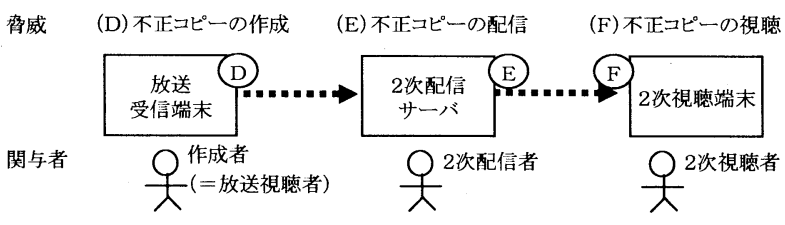

图 3 不正コピーコンテンツの流通モデル Circulation model of illegal copies. 


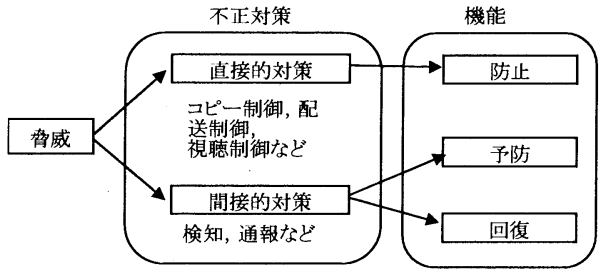

図 4 セキュリティ対策の分類

Categorization of security countermeasures.

コピー制御，不正コピーの配信行為を差し止める配信制 御, 不正コピーの視聴行為を差し止める視聴制御となる. 一方, 間接的対策は検知・通報のように，(a) 不正行為 が起きないように予防したり，(b) 仮に不正行為が起き た場合でも，例えば，海賊版の流通防止などにより，原 状を回復するものである.

最初に, 直接的対策について述べる. 電子透かしを 用いた，海賊版流通の直接的対策としては，DVD 装置 （DVD プレーヤ，レコーダ，PC ボードなど）および関 連装置に電子透かしを装備し, 不正コピーの作成や視聴 を差し止める技術の標準化が検討されており, 効果が期 待されている 29)30).

この技術は,「コピー不可」「一世代コピー可」などの コピー制御情報をコンテンツに埋込んでおき，DVD 装 置において, 埋込まれた情報を検出することによって, コピーの可否を判断し, 制御を行うものである.また, DVD-RAM などの書込み可能な媒体に記録されたコン テンツから「コピー不可」情報を検出した場合に, 不正 コピーと判定して再生を差し止める. 前節で述べたよう に, 電子透かしで埋込んだコピー制御情報は, アナログ 出力を経由した後でも検出できる. したがって, アナロ グ出力経由の不正コピーを直接防止する有効な手段と なる。

次に，間接的対策について述べる．電子透かしを用い て，コンテンツに識別情報を埋込めば，アナログ出力を 経由した後でも検出できるだけでなく, 不正流通に伴う 様々な画像処理, 音響処理が加えられた後でも検出でき る. したがうて, 電子透かしを用いて, 後で不正コピー の流通を検知・通報することができる，例えば，コンテ ンツに著作権者の識別情報を挿入しておき, Web を常時 監視することにより, 当該著作権者のコンテンツが不正 コピーされ, 流通していることを検知し, 著作権者に通 報することができる.

電子透かしを用いた不正コピーの検知・通報手段とし て現在知られているものには，以下の二つがある.

・上記した Web の常時監視のような流通の監視によ る検知・通報 ${ }^{18)}$

・ 2 次視聴端末でコンテンツを処理するときに不正コ ピーであることを検知・通報 ${ }^{6)}$

これらの手段により, 不正コピーの作成行為, 配信行

\begin{tabular}{|c|c|}
\hline 劦威 & 間接的対策（予防・回復） \\
\hline $\begin{array}{l}\text { (D) 不正 } \\
\text { コピー作成 }\end{array}$ & ○ 不正コピーの作成行為を予防, 被害回復.できる. \\
\hline $\begin{array}{l}\text { (E) 不正 } \\
\text { コピー配信 }\end{array}$ & ○ 不正コピーの配信行為を予防, 被害回復できる. \\
\hline $\begin{array}{l}\text { (F) 不正 } \\
\text { コピー視聴 }\end{array}$ & $\begin{array}{l}\times \quad \text { 自分が通報される可能性のある端末は，市場に受け入 } \\
\text { れられにくい. }\end{array}$ \\
\hline
\end{tabular}

為を検知・通報できる. 一方，不正コピーの視聴行為を 検知・通報することは，2次視聴端末からの通報によっ て技術的には可能である。しかし，自分が通報されるよ うな端末はユーザに受け入れらないので，実際には困難 である. 間接的対策における考察を表 4 にまとめる.

\section{3 電子透かしの重要性}

不正コピーを防止するためには，調べようとするコン テンツが「コピー可」なのか「コピー不可」なのかを， 制御システムが判別する必要がある. また，不正コピー を検知するためには，調べようとするコンテンツが正当 に権利処理されているか，および利用条件に沿って正当 に利用されているかどうかを，検知システムが判別する 必要がある，そのためには，コンテンツの種別や著作権 処理，および利用条件に関わる情報がコンテンツに直接 付加されているか，あるいは，これらの情報が別の場所 にあり，そのポインタ情報がコンテンツに付加されてい ることが必要である。いずれの場合でも，コンテンツに 判定情報が付加されていることが必要である.

コンテンツに判定情報を付加する方法としては，メ夕 データのようにコンテンツに付随した外部データに記述 する方法と, “電子透かしを用いてコンテンツ内に埋込む 方法が考えれられる.

しかし, ディジタル化されたコンテンツがアナログ出 力され, さらに再ディジタル化される過程において, コ ンテンツに付随した外部デー夕は消失する可能性が大き い. また, 不正者の意図的な操作によって，外部データ は容易に除去あるいは改竄されてしまう。したがって, アナログ出力経由の不正コピーを防止するための, コン テンツに判定情報を付加する手段としては, 電子透かし 以外にない. すなわち, 従来技術のセキュリティホール であるアナログ出力経由の不正コピーは, 電子透かしに よってのみ防止することができる.

\section{4 電子透かしの要件}

電子透かしには, 画像処理への耐性と画質劣化の防止 という相反する課題がある. すなわち, 上述した放送コ ンテンツの著作権保護に用いる電子すかしは，アナログ 変換に対して充分な耐性を持っていることが必要である. また，アナログコピーされたコンテンツがネットワーク 配信される際の再ディジタル化・再圧縮処理への耐性も 必要である. 一方, 放送映像としての画質を維持できる ことも必要である. そこで, アナログ変換耐性, 再ディ 
ジタル化・再圧縮耐性, 画質劣化許容範囲について, 技 術要件を明らかにする。

（1）アナログ変換耐性

電子透かしはアナログ経由のコピーを検知するために 用いるので，アナログ変換耐性は必須である.

放送コンテンツにおいては，アナログ VHS 標準モー ドで録画したコンテンツが商品として広く流通している. また，アナログ VHS 録画再生機は広く普及しているの で, 媒体商品の再生映像から私的なダビングを自由に作 れる状況にある.しかし，ダビングにより画質が劣化す るため, 劣化した画質の映像が放送コンテンツ商品とし て扱われることはない。

この状況を鑑みると，アナログ VHSへ 1 回目に標準 モードで録画した媒体からの再生映像の画質が，商用に 供するための最低水準にあるといえる。したがって，提 案方法における放送コンテンツも，これと同等以上の画 質を保護対象とすることが妥当である.

したがって電子透かしの要件は，アナログ VHS 標準 モード 1 回コピーに相当する画像処理に対する耐性で ある・

（2）再ディジタル化・再圧縮耐性

再ディジタル化については特に固有の要件はないが, 再圧縮については固有の要件がある.すなわち，放送局 における 1 度目の圧縮では主に MPEG2 が用いられる が，ネットワークでの不正配信では MPEG4 ベースの符 号化方式が多用される。また, 現在の放送は Standard Definition（SD）および High Definition（HD）で行わ れているが，ネットワーク配信では SD およびそれ以下 の規格（CIF など）が多用される，そこで，異なる符号 化方式の組合せや解像度変換を伴う再圧縮に対する耐性 が必要である。

（3）画質劣化許容範囲

画質劣化の評価対象には, (a) 原画像と, 電子透かし 埋込み画像との差, (b) 原画像を圧縮符号化した画像と, 電子透かし埋込み画像を圧縮符号化した画像の差, があ る. (a)(b) 両方を評価することが望ましい.

電子透かし固有の画質評価方法としては, StirMark ${ }^{31)}$ などがよく用いられる。これらは，静止画を対象とした 評価方法であるが, 動画についての評価方法はまだ確立 していない. そこで, 放送映像の一般的な画質評価方法 を取り上げることとする.

放送映像の画質評価方法としては, PSNR（Peak Signal to Noise Ratio） ${ }^{32)}$ などの客観的な評価法と，人間 の目視に依存した主観評価法がある.ディジタル処理に よる画質劣化の場合, PSNR などの機械的な評価值と人 間にとっての画質が, 絵柄によって大きく相違すること があるので, 主観評価法の利用が一般的である. 特に, デジタル放送では，2 重刺激連続品質尺度法が最も良く 用いられている ${ }^{33)}$. そこで, 電子透かしの画質劣化につ
いても， 2 重刺激連続品質尺度法を用いるのが妥当と考 える.

ITU 勧告によると, 放送のためエンコーダとデコーダ とがタンデムに接続される場合に，最終段階では $3 / 4(75$ \%) の画像で劣化度 $18 \%$ 以下, 残り $1 / 4$ の画像で劣化 度 $36 \%$ 以下となることが，デジタル放送画質要件とな る ${ }^{34)}$. 電子透かしによる画質劣化許容範囲についてもこ れと同等範囲が妥当と考える.

\section{4. 電子透かしの利用方法}

\section{1 本検討の観点}

本章で検討する電子透かしを用いた著作権保護につい ては，従来ネットワーク配信を対象として検討されてき た ${ }^{17) 18)}$. しかし，本検討の対象であるデジタル放送は， 以下の 3 点において, ネットワーク配信とは本質的に異 なっている.

（1）ネットワーク配信では，コンテンツのコピーを 禁止，あるいは制御することが前提となっている。一方, 放送コンテンツは，アナログビデオなどを用いてコピー されることを前提に放送されている.

（2）ネットワーク配信方式は短いサイクルで改良・ 変更されるため, その時に新しい著作権保護技術を導入 することができる，一方，放送方式は ARIB などで標準 化され，長期間にわたって固定的に使用される．このた め, 一旦決められた放送方式の中に新たに著作権保護技 術を組込むことは困難である.

（3）ネットワーク配信の受信機は，PCなどの耐夕 ンパー性の不充分な装置が用いられる場合が多い上，一 律の標準化は困難である。一方，デジタル放送の受信機 は，耐タンパー性のあるハードウェア装置が用いられる 上，一律に標準化がなされる.

以上の相違のゆえに，電子透かしを用いた著作権保護 技術の確立のためには，既存の検討に加え，以下の観点 から新たな知見を与える必要がある.

（1）ネットワーク配信では，コピーの防止が主要課 題であり，電子透かしを用いたコピーの検知・通報は補 助的であった. しかし, デジタル放送ではコピーの防止 はできないので，電子透かしを用いたコピーの検知・通 報は本質的な課題となり, その実施は社会インフラとし て，より広範なものとなる. そこで, 社会インフラとし てのコストおよび効果の見積もりを行って, 実現の難易 度を検討する必要がある。 また, 電子透かしの技術要件 についても，放送コンテンツとしての画質およびアナロ グ耐性について，固有の検討が必要である.

（2）既存の放送方式（例えば，CAS や符号化）を変 更することは不可能なので，電子透かし利用システムは， 既存方式の外側に追加する形で構築する必要がある.

（3）受信機に電子透かし装置を装備するなど，受信 機が耐タンパー性のある標準装置であることを有効利用 
することが望ましい.

\section{2 検知・通報の種類とその特性}

3.2 節で述べたように, 電子透かしを用いた検知・通 報の方法は, 流通の監視と 2 次視聴端末での監視に分類 することができる.

最初に, 流通を監視するシステム（流通監視エージエ ント）を用いての検知・通報について分析する．流通の 監視は，さらにネットワーク流通の監視と可搬媒体流通 の監視に分類できる.ネットワーク流通の監視では, 通 信途中のコンテンツを検査することは困難であるから, 通信前あるいはキャッシング状態のコンテンツを検査す ることになる. 例えば, Web サイトに掲載されたコンテ ンツを検査する．しかし，通信前あるいはキャッシング 状態のコンテンツの検査は, 時間およびコストの問題に より, 範囲（例えば，検査できる Web サイトの数）に限 界がある. また, 不正者が Web サイトなどにアクセス 制限を設けて検查を妨害することも可能である. 一方, 可搬媒体流通の監視では, 媒体をプレーヤにかけてコン テンツを再生するなどの人手による処理が必要であるた め, より狭い範囲の検査しかできない. 以上のように, 流通の監視は効果に限界がある.

次に, 2 次視聴端末での監視について分析する. 不正 者が不正コピーの流通をいかに巧妙に行ったとしても, 最後に不正コピーは 2 次視聴端末で視聴される. その点 において，2 次視聴端末での検知・通報は極めて確実性 の高い方法である. この方法の問題点は, 電子透かしを 多くの 2 次視聴端末に装備することの実現性である. た だし, 電子透かしを標準装備することまでは必要ない. 例えば, 全国の 2 次視聴端末の $1 / 10$ に装備されただけ でも，検知・通報の効果は充分期待できる.

電子透かしを用いた検知・通報の方法は, 下記の二つ のレベルに分類することもできる.

・低レベル：単に不正コピーが流通しているという事 実を検知・通報するレベル

・高レベル : 不正者 (不正コピーの作成者, 配信者あ るいは視聴者）を特定して通報するレベル

後者の不正者特定の方が効果は大きい.

まず，不正コピーの作成者を特定するためには，コン テンツを受信した受信機あるいはその利用者の識別情報 を埋込むことが必要である.

次に, 配信者の特定については, ある Web サイトから 不正コピーを検知した場合に, その Web サイトが不正 コピーの配信者であると判断できる.したがって，コン テンツが不正コピーか否かを判断するための情報（利用 条件など）の夕埋込んでおけばよく, 配信者の個別情報 を埋込んでおく必要はない. 最後に, 不正コピーの視聴 者を特定することは， 3.2 節で述べたように困難である.

\section{3 電子透かしの利用方法の分類}

本説では, 電子透かしの㨂入および検出の場所により
電子透かしの利用方法を分類する. 図 1 より，その場所 の候補として, 放送局, 放送受信機, 2 次配信サーバ, 2 次視聴端末が挙げられる. また，それ以外に，流通監 視エージェントがありうる.

これらの場所における挿入と検出の組合せの内, 下記 は除外することができる.

・ 2.2 節で述べたように，本論文では，放送局は不正 をしないことを前提としている. したがって, コンテン ツが放送受信機に届くまでは, 不正がありえないので, 放送局や放送受信機で電子透かしを検出するケースは考 慮する必要がない。

・2 次配信者が不正な場合に, 2 次配信サーバで電子 透かしの㨂入や検出を行うことは考えられない.また， 2 次配信者が不正でない場合には, 元々不正コピーを扱 う可能性がないので，そこで電子透かしの挿入や検出を 行う必要がない.したがって，2次配信サーバでの電子 透かしの挿入および検出を考慮する必要はない。

・3.2 節 (2)で述べたように, 自分が通報されるよう な端末は，ユーザに受け入れられない. したがって，2 次視聴端末で電子透かしを埋込んでも，それを検出する 場面がないため, 2 次視聴端末での埋込みは考える必要 がない.

以上の考察から, 電子透かしを埋込む場所は, 放送局 か放送受信機の 2 通りであり, 電子透かしを検出する場 所は, 流通監視エージェントか 2 次視聴端末の 2 通りで ある（図 5 ）。また，電子透かしの利用方法には，これ らの組合せとして以下の 4 通りの可能性がある.

方法 $1 ：$ 放送局で電子透かしを挿入し, 流通監視エ一 ジェントで検出する

方法 $2 ：$ 放送局で電子透かしを挿入し， 2 次視聴端末 で検出する

方法 $3 ：$ 放送受信機で電子透かしを挿入し, 流通監視 エージェントで検出する

方法 4：放送受信機で電子透かしを挿入し，2 次視聴 端末で検出する

\section{4 従来の研究}

4.1 節で述べたように, 電子透かしを用いた著作権保 護については, 従来ネットワーク配信を対象として検討 されてきた. そこで, 放送とネットワーク配信の相違を 明らかにし, 放送に固有の観点から電子透かしの利用方 法を検討する点が; 本研究の最も重要な新規性である. また, 電子透かしの㨂入および検出箇所という観点から, 放送における電子透かしの利用方法を体系的に分類する 点も, 本研究の新規性である. さらに, 本論文で提案す る方法 1 ～ 4 の使い方は, 放送について検討されていな かった.

方法 1 は, $\mathrm{cIDf}^{17)}$ など既存のネットワーク流通監視 


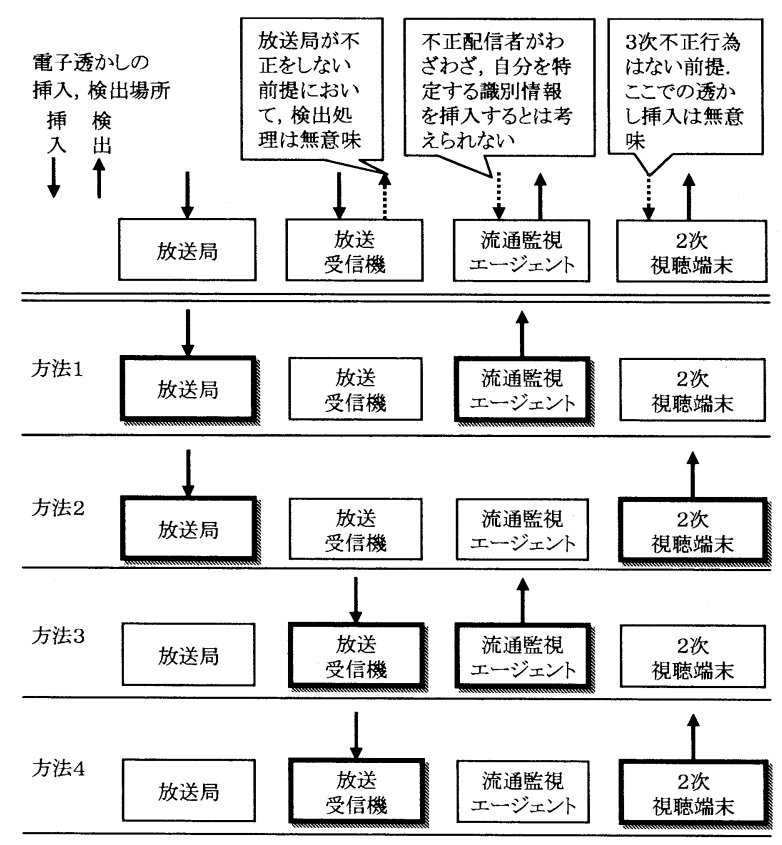

図 5 電子透㫑し挿入・検出場所

Points to embed and to detect watermarks.

フレームワークと類似するが，以下の点が異なる. すな わち, 従来の流通監視技術の目的は, ネットワーク配信 するコンテンツの著作権保護であった. 一方, 提案方法 は放送コンテンツの著作権保護を目的とする. また, 従 来の流通監視における電子透かしの技術要件としては, 例えば，高圧縮符号化に対する電子透かし耐性が重要で あった. 一方, 提案方法の電子透かしの技術要件ではア ナログ変換耐性が重要である．また，従来の流通監視技 術の運用方法では, コンテンツの利用状況によって違法, 合法が分かれていた．このため，通報前にメタデータに よる利用状況の確認などが必要であった。一方, 放送コ ンテンツはネット上に流れたこと自体が違法である。よ り厳密には著作権法第二条九の五により, インタネット に接続されたパソコンに放送コンテンツを載せるなど, 自動送信可能な状態にすることだけで違法である.この ため, 方法 1 のような検討は行われてこなかった.

方法 2 と類似した先例として, 総務省から 2 次視聴端 末での視聴制御に電子透かしを用いる提案 ${ }^{6}$ が示されて いるが，上述した従来の流通監視技術と同様に，ネット ワーク上のコンテンツに対する著作権保護方法である. したがって, 方法 1 について述べた比較論と同様に, 総 務省の提案は目的, 電子透かしの技術要件および運用方 法の点で提案方法と異なる.

方法 3 と類似した先例として, コンテンツにユーザ ID を電子透かしで挿入する利用法（フィンガープリンティ ング）が示されている ${ }^{36) 37)}$. ユーザ ID を挿入する場所 には,コンテンツの送受信を行う際のサーバ側とクライ アント側の 2 種類がある. サーバ側で電子透かしを捚入 する場合は，放送受信機で放送視聴者の ID を埋込む方
法 3 と構成が異なる. クライアント側で電子透かしを㨂 入する場合, 従来の方法ではユーザの手元に透かし埋込 み装置を置くことになるので, 電子透かしのアルゴリズ ムが解読され, 偽造や改ざんの危険性が出てくる課題が あった. 一方, 提案方法は電子透かし埋込久装置をユー ザの手元に置くが, 放送受信機で用いる点が新規である. 放送受信機には耐タンパー措置が施されているので, 内 部の解析が極めて困難である. したがって方法 3 により, フィンガープリンティングをセキュアに具体化できる. さらに放送視聴者 ID を特定した上で通報する手段と組 合せる新しい利用方法を提案している.

方法 4 は, 方法 2 と方法 3 の組合せによる新しい利用 方法である.

\section{5 コスト, 効果および実現性の考察}

本節では, 前節で明らかにした 4 通りの利用方法の特 徵を, コスト, 効果および実現性の観点から考察する.

はじめにコストについて述べる.ここでは, 次の各場 合に電子透かしチップを装備するコストを明らかにする.

(x1) 放送受信機で電子透かし埋込みチップを装備する コスト

(x2) 2 次視聴端末で電子透かし検出チップを装備する コスト

(x3) 流通監視エージェントで電子透かし検出チップを 装備するコスト

(x4) 放送局で電子透かし埋込みチップを装備するコ スト

電子透かし検出には, $50 \mathrm{~K}$ ゲート程度のチップが必要

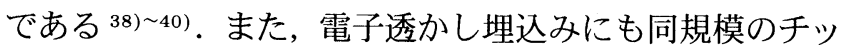
プが必要である. そこで, 普及済みの商用チップとの対 比により, まず $(\mathrm{x} 1)$ の放送受信機で装備するコストを試 算する.

例えば, トランジス夕換算ゲート数 $10 \mathrm{M}$ ゲート程度 の商用 CPU プロセッサは，2002 年 3 月時点で国内実売 価格 $1 \sim 2$ 万円台である ${ }^{41) 42)}$. 放送用の電子透かし透か しチップは, 国内のすべての放送受信機に装備されるの で, 商用 CPU 同様の充分な量産効果が期待できる. し たがって, チップ価格をゲート数で換算することが可能 である. 約 200 分の 1 の規模 ( $50 \mathrm{~K}$ ゲート) の電子透か しチップの単価見込みは, およそ 50 円〜 100 円台とな る.このチップを放送受信機で装備する場合, 放送を受 信する国内世帯数 3000 万世帯の乗算により, (x1) は 15 億円〜 30 億円のコスト規模となる. より正確には，一世 帯に 1 台以上の放送受信機が存在するので, この試算よ りもやや大きなコストになると考えられる. ただし放送 受信機は, パソコンに比べて使用期間が長いので, 将来 的なコストダウンが期待できる.

(x2)の 2 次視聴端末での標準装備の場合, $(\mathrm{x} 1)$ と同規 模のコストを要する．ただし 4.2 節で述べたように, 2 次視聴端末での装備は全体の $10 \%$ 程度でも充分効果が 
期待できるため, 普及率によっては (x1) ほどコストを要 しない.ただし, 量産効果が充分に享受できない場合, $10 \%$ の世帯に普及した時のコストが単純に $(\mathrm{x} 1)$ の $1 / 10$ （1.5～3 億円）とならない可能性もある.これらを考慮 して，(x2) のコスト規模は 1.5〜30 億円と試算する.

放送局や流通監視エージェントに装備する場合, チッ プは数個〜高々数百個あればよく, コストは小さい.こ の場合, 量産効果が得られないため, 同様の試算はでき ない.しかし, 端末台数分必要な $(\mathrm{x} 1)(\mathrm{x} 2)$ と比べれば, (x3)(x4) のコストは大幅に小さいと考えられるので, い ずれも 1.5 億円未満と試算する.

以上の考察をまとめると，下記の試算を得る.

(x1) 15 億円 30 億円

(x2)1.5 30 億円

(x3) 1.5 億円未満

(x4) 1.5 億円未満

ここで, 提案する 4 種類の電子透かし利用方法のコス トは，上記コストの加算として得られる．方法 1 は (x3) と (x4) の加算でコスト「小」（3 億円未満）とする. 方法 2 は $(\mathrm{x} 2)$ と $(\mathrm{x} 4)$ の加算で $3 \sim 31.5$ 億円程度であり, コ スト「中」とする. 方法 3 は $(\mathrm{x} 1)$ と (x3) の加算により 16.5 31.5 億円程度であり, 方法 2 と高々同規模なので コスト「中」とする. 方法 4 は $(\mathrm{x} 1)$ と $(\mathrm{x} 2)$ の加算とな り 16.5～60 億円規模で，コスト「大」とする.

次に, 検知・通報の効果について述べる. 4.2 節で述 べたように，次の 4 種類の検知・通報の方法がある.

(a) 2 次視聴端末（広い監視範囲）で, 不正行為者 を特定

（b）流通監視エージエント（限定された監視範囲） で，不正行為者を特定

（c） 2 次視聴端末で, 不正コピー流通を発見

（d）流通監視エージェントで, 不正コピー流通を 発見

4 種類のうち (a)の効果は最大で, (d) の効果は最小で ある. (a)の場合, 特定した不正行為者に対して, 椇害 賠償や配信差止めなどの直接的な対抗措置を取ることが できる. (d) の場合, 直接的な対抗措置はできないもの の, 不正コピー流通を発見できれば, 間接的な対抗措置 を取ることができる. 例えば，コンテンツの価格を引下 げることにより, 不正コピーの拡散を押しとどめる効果 が期待できる.

(b) と (c) の効果は, いずれも (a) と (d) の中間の効果 となる.ここで, (b) は検知対象により下記のように 2 分できる.

(b1) 限定された監視範囲で不正コピー作成者を特定

(b2) 限定された監視範囲で不正コピー配信者を特定

(b1) は, 限定された監視範囲内でも, 不正コピー作成 者が特定できれば, (a) と同程度の効果が得られる. 一 方, (b2) において配信行為者を特定する能力があっても,
4.2 節で述べたように，限定された監視範囲内に悪意を 持った不正コピー配信行為者がいる可能性は低い，不正 配信者を発見しても, 配信者に悪意がなかった場合, 損 害賠償などによる直接的な原状回復は難しい，配信停止 を促すなど被害拡大防止にとどまることが多いと思われ る.こうした実状を踏まえると，(b2) の効果は実質的に (d) の効果と大きな差違はない.

(c) の場合, 上述した (d) 同様の間接的な効果である が，(d) と比べて監視範囲が広いので, 多くのあるいは 多種類の不正コピーに対して, 対抗措置を取ることがで きる.

ここで，以上の考察をまとめる. (a) と (b1) は直接的 な対抗措置が取れる. (c) (b2)(d) は間接的対抗措置しか 取れない. 検知・通報の効果の大きさは下記の順序と なる.

$$
a>b 1>>c>b 2>d
$$

そこで, 効果については (a) と (b1) を評価○とし, (c)(b2)(d) を $\triangle$ とした. 表 5 は, 前節で明らかにした 4 通りの利用方法の特徵を, コストと効果についてまとめ たものである. 以下で各方法の詳細な分析を行う.

（1）放送局で電子透かしを挿入し, 流通監視エー ジェントで検出する場合（方法 1)

電子透かしシステム（方法 1）の構成を図 6 に示す. 放送局では, 電子透かし㨂入設備により, 何らかの識別 情報を放送コンテンツに㨂入し, 放送電波にのせて放送 する. 例えば，識別情報を放送局 ID とすることにより， 調べようとするコンテンツが放送局のものであることを, 後で判別することができる.

もしも放送受信機において，不正コピーが作成された 場合, 海賊版放送コンテンツは 2 次配信サーバから配信 され，2次視聴端末にて視聴される. このとき, 電子透 かし検出設備を備えた流通監視エージェントにおいて, 海賊版放送コンテンツから識別情報を検出できる. 不正 検知ができれば, 例えば, 放送局 ID と 2 次配信サーバ を特定した上で通報するなどの処置を取ることができる. この場合, 電子透かし挿入設備は, 放送局内に少なく とも 1 個所あればよい. また, 電子透かし検出設備は, 流通監視エージェントに少なくとも 1 個所あればよい. したがって, 表 5 に示すように, 端末で電子透かし㨂入, あるいは検出する場合（端末台数分コストがかかる）と 比べるとコストは小さい.

方法 1 の電子透かし埋込みは放送局が自ら実施でき, また検出も放送関連業界が流通監視エージエントを運営 すればよい.したがって，他の業界との連携や制約を受 けることがないため, 実現性は高い.

方法 1 の検知・通報の効果は, 他の構成と比べて小さ い. 放送局では, 同一のコンテンツを放送するため, 放 送視聴者個人の特定情報を埋込むことができない。した がって, 流通監視エージェントで不正コピーを検知して 
表 5 電子透かし利用方法の比較

Comparison of watermarking applications.

\begin{tabular}{|c|c|c|c|c|c|c|c|c|}
\hline \multirow[b]{2}{*}{ 利用方法 } & \multicolumn{4}{|c|}{$\begin{array}{c}\text { 電子透かし㨂入・検出場所 } \\
\end{array}$} & \multirow[b]{2}{*}{ コスト } & \multicolumn{2}{|c|}{ 検知・通報の効果 } & \multirow[b]{2}{*}{ 評価の理由 } \\
\hline & 放送局 & $\begin{array}{l}\text { 放送受 } \\
\text { 信機 }\end{array}$ & $\begin{array}{l}\text { 流通監視 } \\
\text { エージェ } \\
\text { ント }\end{array}$ & $\begin{array}{c}2 \text { 次視 } \\
\text { 聴端末 }\end{array}$ & & $\begin{array}{l}\text { 不正コピー } \\
\text { 作成行為 }\end{array}$ & $\begin{array}{l}\text { 不正コピー } \\
\text { 配信行為 }\end{array}$ & \\
\hline 方法 1 & $\downarrow$ & & $\uparrow$ & & 小 $(<3.0)$ & $\triangle(\mathrm{d})$ & $\triangle(\mathrm{b} 2)$ & $\begin{array}{l}\text { 放送局と流通監視エージェントだけの設備コストでよい. } \\
\text { 放送業界以外の罢との関わりがないので実現性がよい. } \\
\text { 放送局では個人特定情報の挿入ができないので, 不正コ } \\
\text { ピ一作成行為の検知・通報は困難. 流通監視エージェント } \\
\text { の検知能力は不完全. }\end{array}$ \\
\hline 方法 2 & $\downarrow$ & & & $\uparrow$ & 中 $(3.0-31.5)$ & $\triangle(\mathrm{c})$ & $O(a)$ & $\begin{array}{l}2 \text { 次視聴端末台数分設備コストがかかる. } 2 \text { 次視聴端末で } \\
\text { の透かし検出を標淮装備させることは実現性に困難を伴う. } \\
\text { 一部の装備でも不正コピ一配信行為の抑止が可能. }\end{array}$ \\
\hline 方法 3 & & $\downarrow$ & $\uparrow$ & & 中 (16.5-31.5) & $\bigcirc(b 1)$ & $\triangle(\mathrm{b} 2)$ & $\begin{array}{l}\text { 放送受信機台数分設備コストがかかる. 放送業界以外の業 } \\
\text { 界との関わりがないので実現性がよい. 放送受信機では個 } \\
\text { 人特定情報の挿入ができるので, 不正コピ一作成行為の抑 } \\
\text { 止が可能. }\end{array}$ \\
\hline 方法 4 & & $\downarrow$ & & $\uparrow$ & 大 $(16.5-60.0)$ & $O(a)$ & $O(a)$ & $\begin{array}{l}\text { 2次視聴端末と放送受信機の両台数分設備コストがかかる. } \\
\text { 放送受信機での個人特定情報挿入, } 2 \text { 次視聴端末での検出 } \\
\text { により, 不正コピーの作成, 配信行為を抑止可能. }\end{array}$ \\
\hline
\end{tabular}

電子透かし : 挿入 $=\downarrow$, 検出 $=\uparrow$ コスト : カッコ内は試算, 単位億円

検知通報の効果：(a) 広い監視範囲で, 不正行為者を特定, (b1) 限定された監視範囲で, 不正コピ一作成者を特定,

(b2) 限定された監視範囲で, 不正コピ一配信者を特定, (c) 広い監視範囲で, 不正コピー流通を発見, (d) 限定された監視篹囲で, 不正コピ一流通を発見 $a>b 1>>c>b 2>d$

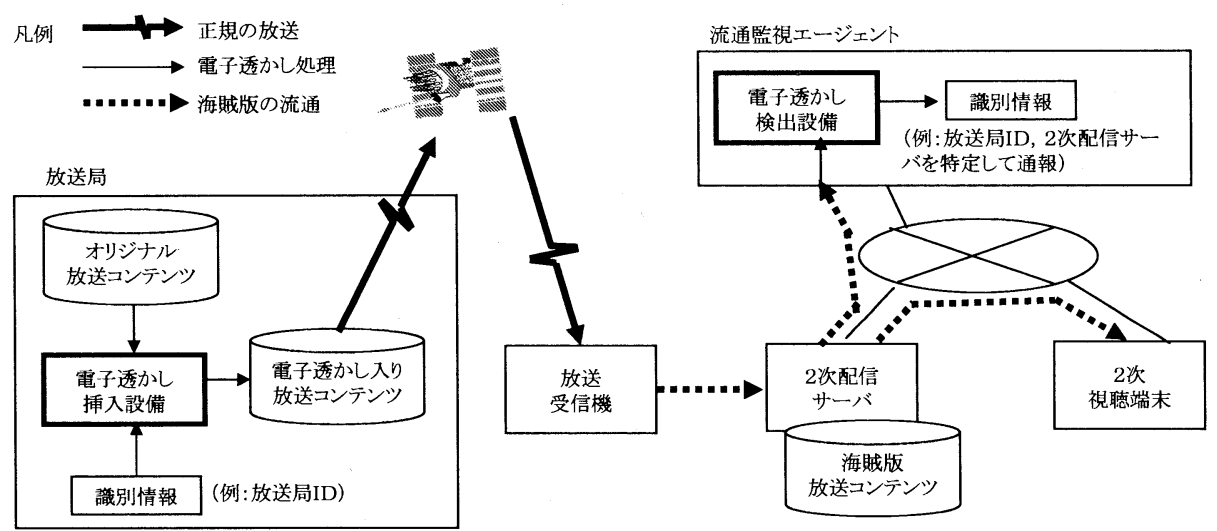

図 6 システム構成図（方法 1 )

System architecture : Method 1.

も，それを作成した放送視聴者を特定することはできな

い. また， 4.2 節で述べたように，流通監視エージェン トの検知能力自体も不充分である.

ここで，方法 1 における電子透かしの技術要件につい て考察を加える. 放送制度は国によって法律が異なるた め，世界一律でその著作権保護を論じることは困難であ る.そこで，日本国内に議論を限定すると，国内の衛星 系一般放送事業者数は 146 社なので，例えば，8ビット あれば充分に識別できる ${ }^{43)}$. したがって，方式 1 の基本 形では， 8 ビットの情報を埋込み，検出するという条件 の下で，3.4 節で述べた耐性と画質劣化に関する技術要 件を満たす必要がある.

さらに，放送局を識別するだけでなく，個々のコンテ ンツを識別したい場合もある，その場合には，例えば コンテンツ ID フォーラム（cIDf）仕様で規定された 64 ビットのコンテンツ ID を用いる ${ }^{17)}$. したがって，この 場合 64 ビットの情報を埋込み，検出するという条件の
下で， 3.4 節で述べた技術要件を満たす必要がある.

（2）放送局で電子透かしを挿入し，2次視聴端末で 検出する場合（方法 2 ）

不正コピーが作成された場合，海賊版放送コンテンツ は 2 次配信サーバから配信され，2次視聴端末にて視聴 される. そして, 電子透かし検出設備を備えた 2 次視聴 端末により，海賊版放送コンテンツから電子透かしを検 出できる.

この場合， 2 次視聴端末台数分コストがかかる.

また， 2 次視聴端末はパーソナルコンピュータなどを 含むので, それらへの電子透かし検出器の装備は, 放送 業界だけでなく, 他の業界との連携や制約を受けるため, 実現への障害が大きい.

放送視聴者の特定情報を埋込めないので，不正コピー 作成行為の検知・通報効果は方法 1 と同じである. 一方, 2 次視聴端末で検出する場合，不正な 2 次配信サ一バを 特定することができる.したがって，4.2 節で述べたよ 


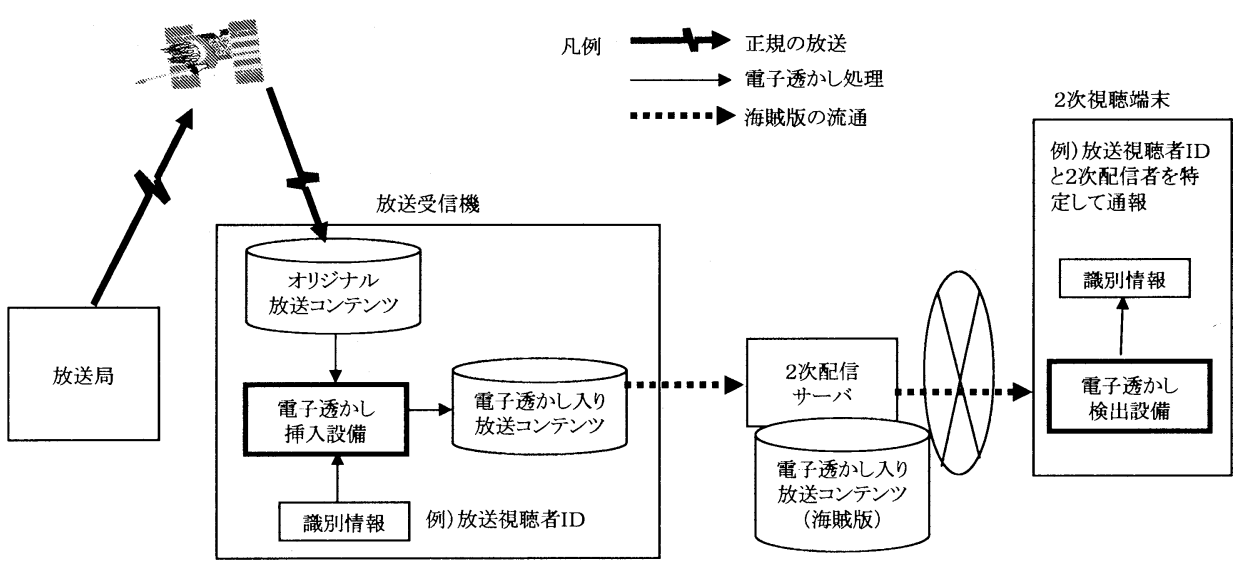

図 7 システム構成図（方法 4)

System architecture : Method 4.

うに，不正配信行為の検知・通報効果は方法 1 のケース より大きい.

なお, 方法 2 における電子透かしの技術要件は, 方法 1 と同様であり, 8 ビットあるいは 64 ビットの情報を埋 込み，検出するという条件の下で， 3.4 節で述べた耐性 と画質劣化に関する技術要件を満たす必要がある.

（3）放送受信機で電子透かしを挿入し，流通監視 エージェントで検出する場合（方法 3 ）

放送局より放送された放送コンテンツは，電子透かし 挿入設備を備えた放送受信機にて受信される。そして， 放送コンテンツの暗号が解かれ視聴されるまでに, 識別 情報を挿入する.

この場合，放送受信機台数分コストがかかる.

また，放送受信機での電子透かし埋込みは放送関連業 界で実施でき, また検出も, 放送関連業界が流通監視 エージェントを運用すればよい. したがって，他の業界 との連携や制約を受けることがないため，実現性は高い.

識別情報として放送視聴者 ID を埋込めば, 不正コピー の作成行為者を後で特定することができる. したがって, 4.2 節で述べたように, 不正コピーの作成行為に対する 検知・通報の効果は方法 1 のケースより大きい.

ここで, 方法 3 における電子透かしの技術要件につい て考察を加える．放送視聴者 ID は 30 ビットあれば, 10 億人の識別が可能であり，（1）で述べたように国内では 充分である. さらに必要に応じて, 方法 1 で述べたよう にコンテンツ ID を識別情報に用いる.したがって，方 法 3 の電子透かしは, 上述した必要ビット数を識別情報 として埋込み, 検出するという条件の下で, 3.4 節で述 べた技術要件を満たさなければならない.

（4）放送受信機で電子透かしを挿入し，2 次視聴端 末で検出する場合（方法 4)

電子透かしシステム（方法 4）の構成を図 7 に示す. 放送受信機において, 方法 3 と同様に, 後で不正コ ピーの作成行為者を特定する識別情報を埋込むことがで きる. 2 次視聴端末において, 方法 2 と同様に, 不正な
2 次配信サ一バを特定することができる.さらに，前記 識別情報を検出することができる.したがって，これら の不正行為者を特定した上で通報することができる.

この場合, 放送受信機および 2 次視聴端末の両端末台 数分のコストがかかるため, コストが最も大きくなる. その一方, 上記方法 2 と方法 3 の長所を兼ね備えるため, 検知・通報の効果は最も大きい.

実現性については，上述した方法 3 と同様に放送受信 機での電子透かし埋込みの点では実現性が高いが, 方法 2 と同様に 2 次視聴端末での検出の点では実現への障害 が大きい.

なお，方法 4 における電子透かしの技術要件は，方法 3 と同様である.

（5）利用方法のまとめと今後の課題

表 5 において，方法 1 は，コストと実現性に優れるも のの, 検知・通報効果が小さい. 一方, 方法 4 はコスト と実現性に課題を残すものの, 検知・通報効果が大きい. 方法 2 および 3 は，これらの中間的な位置づけである.

また，4つの構成うち，2つ以上のシステムの組合せ も可能である. その場合, コスト, 実現の難しさ, 効果 は各々の方式の和となる，例えば，放送局と放送受信機 で電子透かしを挿入し, 流通監視エージェントと 2 次視 聴端末で検出する場合を考えてみる．この場合，すべて 実装するため，コストは最大となる，また，関与者が全 体に及ぶため，実現性は最小となる，一方，効果の方は， 期待しうる最大の効果が得られる. 電子透かしの利用に あたっては，これらの特徽を考虑するべきである.

方法 1 および 2,3 で, 検知・通報の効果が小さい理 由は本質的なものであるため, 今後効果を大幅に向上さ せることは困難である．例えば，放送局で電子透かしを 埋込む場合に，個別の視聴者識別情報を埋込むことは今 後とも困難である. また，流通監視エージェントが世界 中の Web サイトの内，限定された範囲しか検査できな い点についても, 今後大幅な改善は期待できない（計算 機やネットワーク性能の向上によって検査できる Web 
サイト数は増加するが，一方，Web サイトの全体数も増 加する. また, Web サイト側での検査の妨害も依然とし て可能である. したがって, 検査可能な Web サイトの 率は大幅には向上しない）。

一方，コストおよび実現性は，今後，実装技術の革新 や普及状況, 新しい運用方式の導入などによって改善さ れうる. 例えば，標準化に伴って電子透かし装備を大量 生産できれば，コストは大幅に引き下げられる。した がって，実現技術や運用技術の向上および標準化活動な どを通じて，コストおよび実現性を向上することが重要 である。

なお，3 次以降の不正流通により，不正なコンテンツ 数が指数的に増加していく劦威がある. 3 次以降の不正 流通が生じるのは，以下の二つの場合である.

- 2 次流通での不正行為を検知する前に 3 次流通に流 れる場合（監視の速度より被害拡大速度が速い）

・ 2 次流通での不正を検知できない状態にコンテンツ を改変加工された場合（監視能力の質的な限界を超えた 状態)

前者では，監視能力の量的な向上が必要である．例え ば， 2 次視聴端末での透かし検出器の装備を，さらに普 及させることで，監視能力を高めることができる．後者 は, 監視能力の質的な課題である. 例えば, 異なる種類 の加工に強い複数種類の電子透かしを挿入することで, 多様な加工への耐性を確保するなど, より耐性の高い電 子透かし技術の開発が必要である。

\section{5.むすび}

本論文では，ネットワーク配信と放送の相違を明確化 した上で, 放送コンテンツの著作権保護における電子透 かしの利用方法について以下を明らかにした.

・従来の著作権保護技術では, 放送受信機のアナログ 出力を介して, 不正コピーの作成および配信の可能性が ある。

・電子透かしは, 不正コピーの作成および配信の検知・ 通報に有効利用できる.

・電子透かしの技術要件は : (a) アナログ VHS1 回コ ピー相当のアナログ耐性に加え, 再ディジタル化および 再圧縮への耐性があること, (b) 画質劣化許容範囲は 2 重刺激連続品質尺度法を用いて $3 / 4$ の画像で劣化度 18 $\%$ 以下, 残り $1 / 4$ の画像で劣化度 $36 \%$ で斉むこと, で ある。

・電子透かしの有効な挿入場所は, 放送局と放送受信 機であり, 有効な検出場所は流通監視エージエントと 2 次視聴端末である. 有効なシステム構成はこれらの組合 せとして 4 通りある.

さらに，4 通りのシステム構成の特徵を, コストと効 果の観点から明らかにした. これらのシステムを実用化 するにあたって, 今後, 以下の課題を解決することが必
要である.

・放送受信機および 2 次視聴端末への電子透かし機能 の装備は, 不正コピー対策の効果が大きい反面, 装備の コストが大きい，そこで, 装備コストを低減するための 実現および運用方式の確立が重要である.

・ハイビジョンを含む高品質コンテンツに適用可能な, 画質劣化の少ない電子透かし方式であって, しかも, ア ナログ変換後にも安定した検出が可能な方式を策定する ことが必要である.

- 3 次以降の不正流通を阻止するために, より加工耐 性の高い電子透かし技術の開発が必要である. 例えば, 異なる種類の加工に強い複数種類の電子透かしを挿入す ることで，多様な加工への耐性を確保する多重透かし技 術の開発が必要である.

今後はこれらの課題を解決し, 著作権保護技術として の電子透かし利用方法を確立して行きたい. 最後に, 本 研究にあたり熱心な議論をして頂いた，NHK放送技術 研究所次世代符号化グループの皆様，および日立製作所 関係部署の皆様に感謝致します.

\section{〔文献〕}

1）総務省編：“平成 12 年度版情報通信白書”, 第 3 章 情報通信政策の動向, ぎょうせい, (2001)

2）西正: “デジタル放送革命”, プレジデント社 (2001)

3）吉村俊郎: “ディジタル放送システム”, 情報処理, 41, 08,pp.939-944(2000)

4）八木伸衍吉村俊郎加井謙 -..郎：“デ一夕放送技術読本 $\mathrm{BS} / \mathrm{CS} /$ 地上デジ 夕ル放送”，才ーム社 $(2002)$

5）経済産業省商務情報政策局監修：“デジタルコンテンツ白書 $2001 ”$, デジタ ルコンテンツ協会 $(2001)$

6）総務省 デジタルコンテンッのネットワーク流通市場形成に向けた研究会 : “デジタルコンテンツの著作権などの保護とネットワーク流通の円滑化に向 けて”, (2001) http://www.soumu.go.jp/

7）総務省編：“平成 13 年版情報通信白書”, 第 3 章 情報通信政策の動向, 第 4 節 コンテンツの振興 (2002)

8）総務省 平成 13 年度情報通信審議会答申：“讙問第 2003 号「大容量蓄 積機能を活用するデジタル放送方式に関する技術的条件」のうち「B S デ ジタル放送用受信機等が対応可能な権利保護方式の技術的条件」"(2002)

9）経済産業省メディアコンテンツ課：コンテンツ産業政策の課題と方向性 について (改訂版), http://www.meti.go.jp/policy/media_contents/ (2001)

10) Ingemar J.Cox, Matthew L.Miller, Jefferey A.Bloom : "DIGITAL WATERMARKING", Morgan Kaufmann Publishers(2002)

11) Neil F.Johnson, Zoran Duric, Sushil Jajodia : "Information Hiding : Steganography and Watermarking - Attacks and Countermeasures", Kluwer Academic Publishers(2001)

12）松井甲子雄: “電子透かしの基礎，森北出版株式会社”，(1998)

13）佐々木良一・吉浦 裕・手塚悟・三島久典：“インターネット時代の情報セ キュリティー暗号と電子透かし" (2000)

14）映像情報メディア学会編：“デジタル放送局システムのしくみ”，オーム社 (2001)

15）電波産業会：“BS デジタル放送限定受信方式”, ARIB STD-B25 3.0 版 (2001)

16) Bill Rosenblatt, Bill Trippe and Stephen Mooney : "Digital Rights Management, Business and Technology", M \& T Books(2001)

17) Content ID Forum: “CIDF 仕様書”, http://www.cidf.org/(2002)

18）櫻井紀彦, 木俵豊, 高嶋洋一, 谷口展郎, 難波功次: “コンテンツ流通におけ る著作権保護技術の動向”, 情報処理, トランザクション「データベース」 Vol.42 No.SIG15 - 007(2001)

19) Ross J. Anderson : "Security Engineering: A Guide to Building Dependable Distributed Systems", John Wiley \& Sons, Inc.,pp.288-316(2001)

20）剛本宏大: “デジタル放送とインタフェース”, 映情学誌, 55, 6, pp.787$790(2001)$

21) HDCP Specification revision 1.0, http://www.digital-cp.com/

22）電子情報技術産業協会, “VBI を用いたビデオ ID 信号伝送方法”,CPR- 
1204(1997)

23）村田敏則：“デジタル技術による放送サービスの革新と課題”, 日立技術士 会ニュース第 34 号, pp.2-4(2001)

24）社団法人電波産業会：“BS /広带域 CS デジタル放送運用規定技術資料”, ARIB TR-B15 2.2 版 (2002)

25) Macrovision, http://www.macrovision.com/

26）馬場秋継：“アナログコピー制御技術（1）〜マクロビジョン〜”，映情学 誌, 56, 12, pp.1924-1925(2002)

27) CPTWG, http://www.cptwg.org/

28）佐々木良一, 宝木和夫, 桜庭健年, 寺田 真敏, 浜田成泰 : “インターネットセ キュリティー基礎と対策技術”，才ーム社，pp.23-30(2000)

29）森本典繁: “電子透かし技術”, 電子情報通信学会誌 1999 年 08 月号,pp.836838

30) DVD Forum, http://www.dvdforum.org/

31) StirMark, http://www.cl.cam.ac.uk/fapp2/watermarking/ stirmark/

32）池田宏明, Poudel Bed Prasad, 小町祐史 : “AV システムの品質評価 (QA) の必要性と標準化”，画像電子学会第 5 回 VMA 研究会資料 (2000 年 7 月 28 日)

33）中須英輔： “ビデオ系の品質評価〜デジタル符号化テレビ画像の評価を中心 に〜”, 画像電子学会第 5 回 VMA 研究会資料 (2000 年 7 月 28 日)

34) Rec. ITU-R BT.1122-1, "USER REQUIREMENTS FOR EMISSION AND SECONDARY DISTRIBUTION SYSTEMS FOR SDTV, HDTV AND HIERARCHICAL CODING SCHEMES", http://www.itu.int/

35）江島將高, 宮崎明雄, 丸山健治：“印刷画像に対する電子透かし方式の検 討”, 信学論, J82-A, 7, pp.1156-1159(1997)

36）竹内一樹，小舘亮之，富永英義：“画像コンテンツ内容に基づく I D抽出と その応用について”, 情報処理学会電子化知的財产・社会基盤研究会報告 10-3, pp.15-22(2000.11.24)

37）三浦信治，渡辺創，嵩忠雄 : “サーバの不正も考虑した電子透かし法につい て”, 1997 年暗号と情報セキュリティシンポジウム講演論文集, SCIS'97$31 \mathrm{C}(1997)$

38) Matt L. Miller, Ingemar J. Cox, Jeffrey A Bloom: "Watermarking in the Real World:An Application to DVD", Multimedia Security Workshop, ACM Multimedia '98, Bristol, UK, Sept. 12-16, 1998. GMD Report 41, Ed. J. Dittmann, P. Wohlmacher, P. Horster and R. Steinmetz, 71-76, (1998)

39) Millennium Group: "Millennium Group Update", CPTWG, September 20, 2000, http://www.cptwg.org/

40) Galaxy Group: "Galaxy Watermark Proposal Version 1.1", DVDWG Document 99/CFCR02-3

41）“最新C P U全域測定”, DOS/V Magazine 2002-3.15, pp98-125(2002)

42) “CPU ROAD MAP", PC Magazine 2002-2.12, pp107-115(2002)

43）総務省：“平成 14 年版情報通信白書”, 第 2 章第 3 節 1 （1）事業者数, http://www.johotsusintokei.soumu.go.jp/whitepaper/ja/h14/

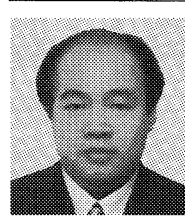

山田 隆亮 1988 年, 京都大学工学部資源工学科卒 業. 同年, 日立製作所に入社. 大森ソフトウェアエ場を経 て, 現在, システム開発研究所第 7 部（セキュリティシス テム研究部) 主任研究員. マルチメディア応用, コンテン ツ流通システムの研究に従事. 正会員.

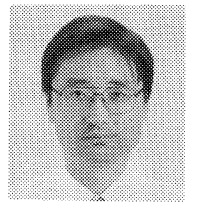

㖎浦裕 1981 年, 東京大学理学部情報科学科 卒業. 同年日立製作所入社，日立研究所，システム開発研究 所に勤務. 2003 年より, 電気通信大学電気通信学部人間コ ミュニケーション学科助教授. 自然言語処理, 知識処理, 情 報セキュリティ，著作権保護の研究に従事．理学博士

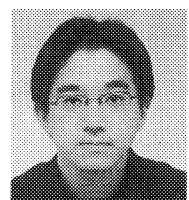

越葥

功 1995 年, 東京工業大学理学部応用物 理学科卒業. 1997 年, 同大大学院修士課程修了 (応用物理 学)，同年日立製作所入社，システム開発研究所配属，情報 セキュリテイ技術，画像用電子透かし技術の研究開発を担 当. 現在, 同研究所第7部 (セキュリティシステム研究部) 研究員. I学博士. 正会員.

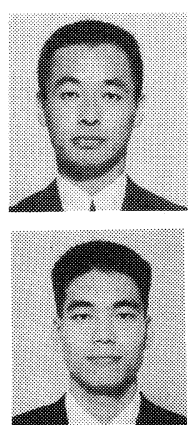

小声架 かず 1987 年, 東京大学工学部電子工学科卒 業，同年，NHKに入局．甲府放送局技術部を経て，1991 年より, 放送技術研究所に勤務. コンテンツ流通システム, 著作権保護用画像処理の研究に従事. 正会員.

荎势冕郎 1998 年, 早稻田大学大学院理工学研究 科材料工学修士課程修了。同年, NHK入局. 放送技術局 を経て, 2000 年より放送技術研究所に勤務. 2003 年より, 放送技術局に所属.コンテンツ流通システム，著作権保護 用画像処理の研究に従事. 正会員.

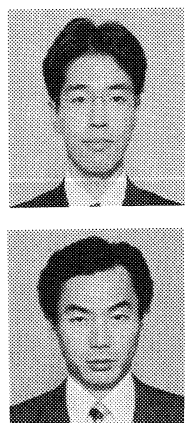

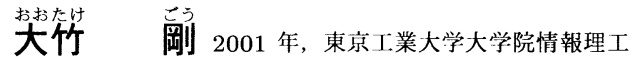
学研究科修士課程修了. 同年, NHK入局. 放送技術研究 所においてコンテンツ流通システム，著作権保護用画像処 理の研究に従事. 正会員.

合志 清—— 1981 年, 早稻田大学理工学研究科博士 前期課程修了. 同年, NHK入局. 1984 年より, 放送技術 研究所にて映像信号のディジタル信昂処理・伝送の研究に従 事. 1995 年，技術局に転じ、ディジタル伝送機器の開発・ 整備に従事. 1999 年より, 放送技術研究所にてコンテンツ セキュリティの研究に従事. 現在, 同研究所次世代符号化 主任研究員. 工学博士. 泟会員. 